\title{
Sorbán Kinga
}

\section{A bosszúpornó és deepfake pornográfia büntetőjogi fenyegetettségének szükségességéről}

\author{
On the necessity of criminalizing revenge porn \\ and deepfake pornography
}

\begin{abstract}
Absztrakt
A közösségi média és a mesterséges intelligencia alapú tartalomszerkesztő alkalmazások könnyü hozzáférhetősége kimondottan kedvez az olyan újfajta tartalmak közzétételének, mint a bosszúpornó (revenge porn) és az algoritmusok által manipulált felvételek (deepfake). Ezeknek a tartalmaknak a közzététele Magyarországon jelenleg nem képez külön tényállást a büntető törvénykönyvben. Más országokban már élénk szabályozási diskurzusok folynak a jelenség büntetendővé nyilvánításáról. Az, hogy az USA, Németország, Franciaország, Olaszország és az Egyesült Királyság is megtette a kezdő lépéseket ebbe az irányba, azt mutatja, hogy olyan problémáról van szó, amely országtól és régiótól független, és amelyre figyelni kell. A jövőbeli szabályozás alapjogi szempontból talán az egyik legjelentősebb kérdése az, hogy az egyének számára okozott sérelem indokolja-e a közléstípus előzetes, teljes tilalmát és a szólásszabadság büntetőjogi eszközökkel történő korlátozását. Az egyelőre kezdetleges állami szabályozás hézagjait jelenleg a platformok magánszabályozás révén töltik ki. Ez egyrészről üdvözlendő, hiszen a felhasználók számára a védelem minimális szintje biztosított. Nem szerencsés viszont abból a szempontból, hogy az egyes platformok eltérő szigorral, szemléletmóddal szabályozzák ugyanazokat a jelenségeket.
\end{abstract}

Kulcsszavak: bosszúpornó, deepfake, pornográfia, platformszabályozás, büntetöjog 


\begin{abstract}
The accessibility of social media and artificial-intelligence-based content editing applications serves as a good starting point for the dissemination of new types of content, such as revenge porn and videos manipulated by algorithms (deepfake). The dissemination of such content does not constitute a standalone criminal act in the Hungarian penal code. In other countries, there is a lively legislative debate on the criminalization of these acts. The fact that the USA, Germany, France, Italy and the United Kingdom took the first steps towards solving the issue shows that this is a problem that is independent of countries and regions and should be accounted for. One of the main questions of future legislation is whether the harm caused to the individuals could justify the preliminary ban of these content and the restriction of freedom of speech by criminal law. The gaps in the state laws that are still quite rudimentary are filled by platform providers via private regulation. This is welcomed on the one hand as minimal protection of the users is ensured. However, it poses several problems as each platform regulates the same phenomena with different rigor and with a different approach.
\end{abstract}

Keywords: revenge porn, deepfake, pornography, platform regulation, criminal law

\title{
Problémafelvetés
}

A 2000-es évek elejének egyik városi legendája, hogy ha kiírnánk az internet tartalmát egy CD-re, annak legalább a fele pornográf tartalom lenne. Természetesen ez az arány meglehetösen eltúlzott, a valós adatok már 2010-ben is azt mutatták, hogy a legnépszerübb egymillió weboldalnak csupán a 4\%-a erotikus jellegü (URL1). Tagadhatatlan viszont, hogy az internet kedvez a szexuális jellegü tartalmak terjedésének is. A szexuális tartalmakkal kapcsolatos visszaélések több, jogtudományi szempontból is érdekes kérdést felvetnek, annak ellenére, hogy a szabályozásuk jelenleg nem áll a tudományos érdeklődés középpontjában. Mielőtt azonban rátérnénk arra, hogy mit értünk pontosan visszaélések alatt, a kontextus megteremtése érdekében érdemes néhány szót ejteni a pornográfia szabályozásáról általánosságban. A téma összetettségét illusztrálja, hogy a pornográfiaszabályozás jogtudományi szempontból három síkon is vizsgálható: alkotmányjogi, tartalomszabályozási és büntetőjogi síkon. Az alkotmányjogi síkon a pornográfia és a szólásszabadság egymáshoz való viszonyát érdemes górcső alá venni, míg a tartalomszabályozás síkján elsősorban azokról a médiajogi szabályokról kell 
szólni, amelyek közérdekvédelmi indokkal teszik lehetővé a tartalomterjesztés korlátozását. A három sík közül a legtöbb kurrens kérdés a büntetőjogi síkon merül fel. A tanulmány szerzője már a címválasztáskor is tudatosan tartózkodott a büncselekmény kifejezés használatától, föként amiatt, hogy a vizsgált magatartások között több olyan is van, amely esetében élénk szabályozási-jogpolitikai diskurzus folyik büntethetőségről, illetve a büntetendőségről. Jelen tanulmány egyik célja, hogy bemutassa azokat a visszásságokat, amelyek napjainkban a szexuális tartalmakkal kapcsolatban merülnek fel, és feltárja, hogy ezek kezelésére a jelenlegi jogszabályi kereteken belül rendelkezésre állnak-e adekvát megoldások. A szabályozási megoldások között a tanulmány különös figyelmet szentel a büntetőjognak, azt vizsgálva, hogy vajon indokolt-e az ultima ratio jellegü eszközökhöz fordulni, ha szexuális tartalmakkal kapcsolatos visszaélésekről van szó, és ha igen, indokolt-e új tényállások megalkotása, vagy elegendö-e ezeket a cselekményeket a már meglévő rendelkezések keretei között kriminalizálni. A szexuális tartalmakkal kapcsolatos jogellenes cselekmények az online térben számtalan formában megvalósulhatnak, éppen e sokszínüség miatt a problémahalmaz kezelésére nem adható uniformizált, egységesen alkalmazható megoldás. Ahogyan a jogellenes magatartások is különböző formákat ölthetnek, az ezekre adott válaszoknak is differenciáltaknak kell lenniük. A leírtak képletesebb szemléltetése érdekében vizsgáljuk meg annak a skálának a két végpontját, amelyen a pornográf tartalmakkal kapcsolatos jogellenes magatartások elhelyezkednek. Önmagában a pornográf tartalmak nagy részének a közzététele az interneten nem jogellenes, a sérülékenyebb felhasználói csoportok - különösen a kiskorúak - védelme azonban indokolhatja bizonyos tartalmi korlátok felállítását. E korlátok többnyire azt hivatottak biztosítani, hogy egyes felhasználók ne férjenek hozzá a számukra nem megfelelő tartalmakhoz, a célközönséget azonban nem céljuk elzárni az ilyen típusú alkotások megtekintésétől. A hozzáférést korlátozó szabályok ebben az esetben médiaigazgatási, közigazgatási jellegüek, és a normaszegő magatartás szankciója is ehhez igazodik. Teljesen más a helyzet a skála másik végén, a gyermekpornográf felvételek esetében. Ezeknél nem csupán az a cél, hogy a teljes potenciális közönséget elzárjuk a hozzáféréstől, de az is, hogy a fogyasztók és az előállítók felelősségre vonása büntetőjogi szankciókkal megtörténjen. A skála két végpontja között azonban több olyan eset található, amelyek esetében a sérelmet elszenvedő fél akaratától függ, hogy büntetőjogi útra tereli-e az ügyet. A személyiségi jog megsértésével járó cselekmények esetében a büntetőjogi szankcióval való fenyegetettség több esetben fennáll, de a büntetőeljárás nem szükségszerü velejárója a jogsértő cselekménynek. A személyiségi joggal kapcsolatos büncselekmények többsége ('igy például a rágalmazás és a becsületsértés) is magánindítványra büntethető, vagyis 
magánvádas eljárás, ahol nem az állam, hanem maga a sértett léphet fel büntető igényével. Többnyire azonban a személyiségi jogsértések esetén a magánjogi igényérvényesítés a domináns, mivel polgári peres eljárás keretében is lehetőség van jóvátételt kérni, ami a sértett oldalán gyakran egyszerübb és gyorsabb módja az ügy rendezésének. A hagyományosnak mondható gyermekpornográfia és a közszereplőkről készült intim felvételek kiszivárogtatása mellett megjelentek olyan újfajta tartalmak is, amelyek előállításának és terjesztésének kimondottan kedvez a közösségi média és a mesterséges intelligencia alapú tartalomszerkesztő alkalmazások könnyü hozzáférhetősége. Ilyen újfajta jelenség a bosszúpornó (revenge porn) ${ }^{1}$ és az algoritmusok által manipulált felvételek (deepfake) ${ }^{2}$ közzététele. A bosszúpornó és a deepfake pornográf felvételek, mint Parti Katalin és szerzőtársai által cyberdevianciaként (Parti et al., 2019) jellemzett magatartások esetében szóba jöhet több büntetőjogi tényállás is, így a becsület csorbítására alkalmas hamis hang- vagy képfelvétel készítése, rágalmazás, szexuális kényszerítés, esetleg zsarolás is felmerülhet, ezek közül azonban nem mindegyik magánvádra üldözendő cselekmény, a sértett számára nem indifferens, hogy melyik képezi az eljárás tárgyát. Noha mind a pornográfia, mind a bosszúpornó, mind a deepfake pornográfia esetében szexuális tartalmakról van szó, a korlátozhatóság szempontjából mégsem lehet őket azonosan kezelni. A pornográfia célja alapvetően a szexuális vágykeltés - előállítására egy egész iparág jött létre-, és haszonszerzési céllal történik, a felvételek szereplői pedig beleegyeztek abba, hogy szexuális cselekményükről felvétel készül és az a nyilvánosság számára elérhető lesz. A másik két esetben a beleegyezés - akár a felvételkészítésbe, akár a közzétételbe, akár mindkettőbe - hiányzik. A bosszúpornó közzétételének motivációja teljesen más, hiszen ebben az esetben a közzétevő fő célja a felvétel egy vagy több szereplöjének megalázása, vagyis sérelem okozása. A kettő között lehet elhelyezni a deepfake pornográfiát, amelynek jellemzően hírességek az áldozatai. Az előállító célja részben az áldozat megszégyenítése, kellemetlen helyzetbe hozása a nyilvánosság elött, másrészt azonban célja a rajongói fétisek és fantáziák kiszolgálása is. A pornográf tartalmú közlések korlátozhatóságának alkotmányossága a büntetőjogi vizsgálat szempontjából is kiemelt jelentőségü: az alapjogok büntetőjogi korlátozása csak kivételes esetben igazolható és szigorú feltételek fennállása esetén lehetséges. Tanulmányomban amellett érvelek, hogy míg a hagyományos pornográfia esetében kevés az olyan

1 A bosszúpornónak jelenleg nincsen elfogadott általános definíciója. Jelen tanulmány a bosszúpornó kifejezést azokra a szexuális tartalmakra használja, amelyeket az abban szereplő személy(ek) hozzájárulása, tudta nélkül készítettek és/vagy tettek közzé a világhálón.

2 Deepfake pornográfiának nevezzük azokat a szexuális tartalmakat, amelyeket algoritmusok segítségével, valós felvételek montázsolásával készítenek el. 
külső korlát, amely a büntetőjogi szankcióval történő fenyegetést indokolná, a bosszúpornó és a deepfake pornográfia esetében minden esetben van, hiszen mindkettő egyéni jogokat sért.

\section{A pornográf tartalmak korlátozása, és a szólásszabadság védelme}

Mivel a médiajogi tartalomszabályozás, illetve a jogsértő online tartalmak eltávolítását lehetővé tévő büntetőjogi eszközök természetszerüleg felvetik a szólásszabadság korlátozásának a lehetőségét, indokolt röviden kitérni a téma alapjogi oldalára. A magyar Alkotmánybíróság praxisában csak a sajtószabadsággal összefüggésben találunk az erotikus, illetve pornográf tartalmak és a szólásszabadság összefüggéseit boncolgató határozatokat ${ }^{3}$, így mindenképp tisztázandó: maga a pornográfia és azon belül a bosszúpornóként közzétett, illetve az algoritmusok segítségével manipulált deepfake pornográf tartalmak alkotmányjogi szempontból védendő közléseknek, beszédnek minősülnek-e, s ekként megilleti-e őket az alapjogi védelem. A jelenlegi alkotmányjogi gyakorlat alapján ${ }^{4}$ a hagyományos pornográfia élvezi a szólásszabadság védelmét, ezért a tartalomterjesztés korlátozását, jellegétől függetlenül, szigorú mérce alkalmazásával kell vizsgálni, hiszen akár médiaigazgatási, akár büntetőjogi jellegü intézkedésekről beszélünk, a vizsgált intézkedésnek meg kell felelnie a szükségességi-arányossági teszt követelményrendszerének. Az Emberi Jogok Európai Egyezménye lehetővé teszi a közlések korlátozását arra hivatkozással, hogy azok sértik a közerkölcsöt ${ }^{5}$, ez azonban a pornográf tartalmak esetében nem jelentheti az ilyen típusú közlések teljes tilalmát. Lábady Tamás és Sólyom László alkotmánybírók 20/1997. (III. 19.) AB határozathoz füzött különvéleménye szerint ,a közerkölcs - mint olyan elvont érték, amely mögött a legkevésbé állapitható meg egyes egyéni alapjogok sérelme - a véleményszabadság korlátozására alkotmányos mércével mérve a legkevésbé alkalmas javak csoportjába tartozik."

3 Lásd: 20/1997. (III. 19.) AB határozat és 165/2011. (XII. 20.) AB határozat.

4 A szólásszabadság és a pornográf tartalmak viszonyáról lásd részletesebben: Koltay, 2009 és Török, 2018.

5 EJEE 10. cikk 2. E kötelezettségekkel és felelösséggel együtt járó szabadságok gyakorlása a törvényben meghatározott olyan alakszerüségeknek, feltételeknek, korlátozásoknak vagy szankcióknak vethető alá, amelyek szükséges intézkedéseknek minősülnek egy demokratikus társadalomban a nemzetbiztonság, a területi sértetlenség, a közbiztonság, a zavargás vagy bünözés megelőzése, a közegészség vagy az erkölcsök védelme, mások jó hírneve vagy jogai védelme, a bizalmas értesülés közlésének megakadályozása, vagy a bíróságok tekintélyének és pártatlanságának fenntartása céljából. 
Ahogyan a hagyományos pornográfia esetében sem elegendő a szólásszabadság korlátozására a közerkölcs sérelmére való hivatkozás, úgy a bosszúpornó és a deepfake pornográf felvételek esetében sem lehetne sikerrel hivatkozni az erkölcs sérelmére. Arra is indokolt felhívni a figyelmet, hogy nem beszélhetünk társadalmi közmegegyezésről azt illetően, hogy az ilyen felvételek közzététele valóban sérti-e az uralkodó társadalmi értékrendet. A 20/1997. (III. 19.) $\mathrm{AB}$ határozatban a testület felhívta a figyelmet a Legfelsőbb Bíróság Polgári Kollégiumának BH1992. 454. számú eseti döntésére, amely meglehetősen elvontan határozta meg a közerkölcs fogalmát, amikor ,...megállapitotta, hogy a közerkölcs fogalmába azok a magatartási szabályok sorolhatók, amelyeket a társadalom általánosan elfogad." Manapság is igen erőteljes az áldozathibáztatás (URL2), mely szerint, aki hagyta, hogy ilyen felvétel készüljön róla az megérdemli, amit kap. A bosszúpornó és a deepfake pornográf felvételek esetében az erkölcsi értékek megsértésénél sokkal markánsabb szerep jut az egyéni jogok megsértésének. Alaptörvényünk a negyedik és hetedik módosítása óta a szólásszabadság korlátozhatóságának egészen konkrét eseteit is ismeri.

\section{A beleegyezés nélkül közzétett és a hamisított szexuális felvételek és a magánélet védelme}

Az Alaptörvény VI. és IX. cikkei szólnak arról, hogy a véleménynyilvánítás szabadságának gyakorlása nem járhat mások magán- és családi életének, valamint otthonának megsértésével, továbbá nem irányulhat mások emberi méltóságának, illetve egyes közösségek méltóságának megsértésére. ${ }^{6}$ Mások jó hírnevének és jogainak védelme az Emberi Jogok Európai Bírósága (EJEB) szerint is a véleménynyilvánítás korlátozásának legitim célja lehet, amennyiben a szólásszabadság joga konfliktusba kerül a magánszféra tiszteletben tartásának az Emberi Jogok Európai Egyezménye (EJEE) 8. cikke által biztosított jogával. A már hivatkozott 20/1997. (III. 19.) AB határozatban Tersztyánszky

6 Alaptörvény VI. cikk

,(1) Mindenkinek joga van ahhoz, hogy magán- és családi életét, otthonát, kapcsolattartását és jó hírnevét tiszteletben tartsák. A véleménynyilvánitás szabadsága és a gyülekezési jog gyakorlása nem járhat mások magán- és családi életének, valamint otthonának sérelmével. “

IX. cikk

„(4) A véleménynyilvánitás szabadságának a gyakorlása nem irányulhat mások emberi méltóságának a megsértésére.

(5) A véleménynyilvánitás szabadságának a gyakorlása nem irányulhat a magyar nemzet, a nemzeti, etnikai, faji vagy vallási közösségek méltóságának a megsértésére. Az ilyen közösséghez tartozó személyek - törvényben meghatározottak szerint - jogosultak a közösséget sértö véleménynyilvánitás ellen, emberi méltóságuk megsértése miatt igényeiket biróság elött érvényesiteni. “ 
Ödön alkotmánybíró különvéleményében kiemeli: azokban az estekben, ahol a szólásszabadság más személyek alapvető jogaival kerül konfliktusba, mindig csak egyedileg, a teljes tényállás ismeretében lehet eldönteni, hogy melyik az elsőbbséget élvező érdek, így „a szólásszabadság és más egyéni alapvetö jogok, úgy mint az emberi méltósághoz, a jó hírnévhez, vagy a magántitok védelméhez ütközését minden esetben egyedileg kell eldönteni és szükségtelen a véleménynyilvánitás szabadságát általánosan korlátozó jogi norma megalkotása". A bosszúból közzétett szexuális felvételek és a becsület csorbítására alkalmas, hamisított, szexuális tartalmú felvételek esetében azonban ez az álláspont már vitatható, hiszen ezekben az esetekben a közlés minden szempontból sérelmet okoz, a cselekmény utólagos bíróság általi megítélése pedig már sokszor kevés ahhoz, hogy a sérelmet mérsékelje. Noha mindkét jelenség elsősorban egyes személyek jó hírnevén, becsületén ejt csorbát, a társadalmi hatásaik túlmutatnak az egyén számára okozott sérelmen. A felvételek általában véve alkalmasak arra, hogy mélyítsék a társadalom egyes csoportjai közötti, különösen a nemek közötti egyenlötlenségeket, mélyítsék az előítéleteket (áldozathibáztatás). A magánélet védelmének szintje eltérő aszerint, hogy az érintettek milyen szerepet töltenek be a társadalom müködésének folyamatában. A közügyeket érintő megnyilvánulások kapcsán szükebbek a korlátozás lehetőségei a közszereplők és a politikusok esetében, akiknek nagyobb mértékben kell tolerálniuk a kritikát, azonban a szólásszabadság védelme még esetükben sem lehet a magánéletez való jog rovására korlátlan. A von Hannover kontra Németország ügyben az EJEB kimondta, hogy a közszerepléssel össze nem függő élethelyzetekben a közszereplőt is megilleti a személyes identitása olyan elemeinek védelme, mint például a képmás. Az Axel Springer AG kontra Németország ügyben pedig az EJEB egy olyan kritériumrendszert is felállított, amely a szólásszabadság és a magánélet védelmének ütközésekor alkalmazandó annak eldöntésére, hogy az adott ügyben melyik jog az erősebb. A szempontrendszer figyelembe veszi, hogy a vitatott közlés mennyiben járul hozzá a közérdekü eszmecseréhez, a közlő milyen módon tett szert az információra, illetve, hogy mi az adott közlés tartalma, formája és következménye. Politikusok vonatkozásában a véleménynyilvánítás szabadsága csak igen szük körben korlátozható, abból az elgondolásból fakadóan, hogy a választópolgároknak joguk van tudni, hogy kire - milyen emberre - adják le voksukat. A választási kampány azonban már felütötte a fejét a politikusi hálószobákban is, és egyre gyakrabban fordul elő, hogy szexuális tartalmú felvételek kerülnek elő politikusokról. Koltay András rámutat, hogy még a politikusok is rendelkeznek védendő privát szférával (Koltay, 2009). A közéleti szereplő magán- és családi életét, valamint otthonát a közéleti szereplőnek nem minősülő személlyel 
azonos védelem illeti meg. ${ }^{7}$ Benjamin Griveaux, aki Párizs föpolgármester-jelöltjeként indult volna a 2020-as választáson, egy szexvideóbotrány miatt volt kénytelen visszalépni (URL3). A közösségi médiában elterjedt felvételeken semmi jogszerütlen nem történt, önmagában pedig az, hogy valaki intim felvételeket küld a szeretőjének, senkit nem tesz közfeladat ellátásra alkalmatlanná, de a politikus - tartva a választópolgárok erkölcsi ítéletétől - mégis lemondott a jelöltségről (URL4). A bosszúpornó jelensége Magyarországon sem ismeretlen. A 2019-es önkormányzati választási kampány egyik legnagyobb botránya egy győri politikus interneten közzétett szexvideója volt, amelyet sikerült ugyan eltávolíttatni, de hamar újra felbukkant online (URL5). A probléma magánszemélyeket is érint és nem is újkeletű. 2016-ban egy salgótarjáni iskolás lányról bosszúból feltöltött felvétel esete vonta magára a sajtó figyelmét (URL6).

\section{A beleegyezés nélkül közzétett, illetve hamisított szexuális felvételek és a szólásszabadság kapcsolata az Egyesült Államokban}

Az Amerikai Egyesült Államokban már 2016-ban is 26 államban létezett olyan törvény, amely tiltja a hozzájárulás nélkül közzétett szexuális tartalmak közzétételét. Ezeknek a törvényeknek az alkotmányossága azonban kérdéses, mivel - ahogyan több más szerző mellett Andrew Koppelman (2016) is rávilágít - ezek a jogszabályok a közléseket, a beszédet a tartalom alapján korlátozzák, ami az Egyesült Államokban tilos, kivéve, ha kényszerítő állami érdekről (compelling state interest) van szó. A Reed kontra Gilbert ügyben a Legfelsőbb Bíróság kimondta, hogy egy közlés korlátozása akkor minősül tartalomalapúnak, ha a korlátozásra a tárgyalt téma, a kifejtett gondolat vagy üzenet miatt kerül sor $^{8}$. A tartalomalapú korlátozás tilalma alól ugyan vannak kivételek - például a gyülöletkeltés, a gyermekpornográfia, az obszcenitás és a magánszemély sérelmére elkövetett becsületsértés -, a bosszúpornónak nevezett jelenség azonban egyik kategóriába sem illik. Az Egyesült Államok kontra Stevens ügyben azt is kimondta a Legfelsőbb Bíróság, hogy a védelmet nem élvező beszéd kategóriáit nem lehet tovább bővíteni. A bíróság álláspontja szerint az alkotmány maga nem olyan dokumentum, amely korlátokat állít, ezért a szólásszabadság korlátait a bíróság állapította meg, és az összes, a bíróság által konstituált kor-

7 2018. évi LIII. törvény a magánélet védelméről 7. § (2) bekezdés.

8 Regulation of speech is content based if a law applies to particular speech because of the topic discussed or the idea or message expressed - Reed v. Gilbert 135. S. Ct. 2218, 2227 (2015). 
lát a védelmet nem élvező közlések régen lefektetett és korábban elismert kategóriáin alapul ${ }^{9}$. A Legfelsőbb Bíróság felfogása szerint a szólásszabadság csak akkor korlátozható erőteljesebben, ha a szóban forgó korlát a gyakorlatban alkalmazott, rég elfogadott, közmegegyezésen alapuló tradíción alapul. A hírértékkel nem bíró, magánjellegü, hozzájárulás nélkül közzétett szexuális tartalmak korlátozásához azonban nem kapcsolódik a társadalom által elfogadott hagyomány, mivel az elmúlt évek egyik újhullámos jelenségéről van szó. További probléma a bosszúpornó korlátozásával az is, hogy a károkozás, amelyen a korlátozás alapulna, nézőpontalapú. Egyes vélemények nézőpont alapján történő diszkriminálása (viewpoint discrimination) pedig az Egyesült Államok jogrendszerében szintén tilos. A Snyder kontra Phelps ügyben a Legfelsőbb Bíróság kimondta, hogy egyes közlések nem tilthatók meg pusztán azon az alapon, hogy a társadalom egy csoportja azokat sértőnek találja, és úgy találta, hogy a szólásszabadság védelmét élvezi az, amikor tüntetők egy Irakban elhunyt katona temetésén ,,Isten utálja az USA-t”, „Köszönöm Istenem a 9/11-et”, „Köszönet Istennek a halott katonákért" feliratú transzparensekkel demonstrálnak. ${ }^{10}$ Ezt a logikát követve Koppelman kifejti, hogy a bosszúpornó esetében a sérelmet az okozza, hogy a közönség, vagy annak egy része elfogadja a közzétevő nézőpontját, azt, hogy a képen, videóban szereplő nő egy mindenre kapható, értéktelen szajha (Koppelman, 2016). A közlés korlátozásával a jogalkotó azt az attitüdöt ítélné meg hátrányosan, amely elítéli azokat a nőket, akikről ilyen felvétel került nyilvánosságra. Koppelman amellett érvel, hogy az amerikai Legfelsőbb Bíróság által meghatározott kivételek a szólásszabadság első alkotmánykiegészítésben biztosított jogának merev értelmezésén alapulnak, ez a merev értelmezés pedig a szólásszabadság alapvetően liberális felfogásából fakad. A szólásszabadság liberális felfogása szerint a szabad véleménynyilvánítás egyrészt a kormányzat korlátozásának, másrészt a nyilvános vitákban, közbeszédben aktívan részt vevő állampolgárok ideájának alapja. A bosszúpornó viszont épp az utóbbira jelent veszélyt, mivel elhallgattatja az áldozatokat és általában mindazokat, akik attól félnek, hogy hasonló cselekmény áldozataivá válhatnak. A szorongó állampolgárok, akik egy-egy felvétel nyilvánosságra kerülése után törlik magukat a közösségi felületekről és másik államba költöznek, feltehetően nem az ideális résztvevői a demokratikus társadalomban folyó közéleti vitáknak. A probléma túlmutat a magánszemélyeknek okozott károkozáson és a magánélet sérelmén. A hozzájárulás nélkül közzétett felvételek politikai hitelrontás céljára is felhasználhatók, ezt mutatja Katie Hill ame-

9 United States v. Stevens, 559 U.S. 460, 470, 471, (2010).

10 Snyder v. Phepls 131 S. Ct. 1207, 1214 (2011). 
rikai politikus példája, aki 2019 novemberében lemondott a Kongresszusban, mert feltehetően a volt férje explicit képeket tett róla közzé, amelyek bejárták az online sajtót (URL7). A közéletből ily módon visszavonulásra kényszerített nők lényegében megfosztatnak attól a lehetőségtől, hogy John Stuart Mill pragmatikus ideájának (Mill, 1994) megfelelően kiteljesítsék személyiségüket és közelebb vigyék a társadalmat az igazsághoz. A bosszúpornó tehát nemcsak az egyének problémája, hanem a demokratikus diskurzusok sokszínúségének egyértelmü veszélyeztetése azáltal, hogy e diskurzusok potenciális szereplőinek elhallgattatásával jár.

Hasonló a helyzet a deepfake pornográfia esetében. A deepfake kifejezés két szó összevonásából keletkezett, a deep arra a mélytanulási technikára utal, amelyet a mesterséges intelligenciát használó algoritmusok képesek elsajátítani, az emberi agyhoz hasonlóan új ismeretanyagokat, a fake pedig hamisat, megtévesztőt jelent. A deepfake pornográfia jelensége 2017-ben került be a köztudatba, amikor hírességek, többek között Gal Gadot (URL8) vagy Scarlett Johansson (URL9) arcait montírozták pornográf felvételekre. A technológia fejlődésének köszönhetően az ilyen felvételek elkészítéséhez nem kell hollywoodi stúdiókat megszégyenítő felszerelés, sem technikai tudás, egy egyszerủ applikációval bárki készíthet hasonló videókat. Éppen ezért a jelenség már nem kizárólag a sztárokat érinti, hanem a hétköznapi embereket is, haragosai bárkiről készíthetnek hasonló digitális kreálmányt. Alkotmányjogi szempontból a deepfake pornográfia két témakört érinthet: a hamis beszédet és az obszcenitás témakörét. A hamis közlések alapjában véve nem minősülnek értékesnek, hiszen nem mozdítják előre a közügyekről folyó diskurzust. Az amerikai bíróságok többnyire azonban vonakodnak a közlések előzetes korlátozásától, a New York Times kontra Sullivan ügyben pedig a Legfelsőbb Bíróság azt is kimondta, hogy csak akkor ítélhető meg kártérítés köztisztséget viselők becsületének megsértése esetén, ha a hamis tényközlést ártó szándékkal tették. ${ }^{11} \mathrm{~A}$ Gertz kontra Robert Welch ügyben ${ }^{12}$ a bíróság azt is kimondta, hogy az egyes államok felállíthatják saját felelősségi rendszerüket a magánszemélynek sérelmet okozó rágalmazó hazugságokért. Douglas Harris viszont kiemeli, hogy a deepfake pornográf felvételek általában nem minősülnek a Miller-teszt szerint obszcénnek: az olyan hamis felvételek, amelyek nem erőszakosak vagy müvészi értéket képviselhetnek, nem korlátozhatók (Harris, 2019). Azt, hogy milyen tartalmak minősülnek obszcénnek, az úgynevezett Miller-teszt segítségével lehet eldönteni, amelyet a

11 N. Y. Times Co. v. United States 403 U.S. 713, 714. (1971).

12 Gertz v. Robert Welch Inc. 418 U.S. 323 (1974). 
Miller kontra California ügyben ${ }^{13}$ dolgozott ki a Legfelsőbb Bíróság. Ez alapján az obszcenitás megítélésekor az alábbi faktorokat kell figyelembe venni:

a) hogy az átlagember, aki kortárs közösségi standardokat vesz figyelembe, úgy találja-e, hogy az alkotás, mint egész kizárólag a szexuális vágy kielégítésére irányul (appeals to the prurient interest);

b) hogy az alkotás sértő módon ábrázol vagy ír-e le szexuális cselekvést;

c) hogy az alkotás, mint egész nélkülözi-e a komoly irodalmi, müvészi, politikai vagy tudományos értéket.

A pornográfia azonban alapjában véve nem minősíthető obszcénnek, csak azok a különösen extrém fajtái, mint a különös kegyetlenséget fetisizáló, állatokkal való fajtalankodást bemutató pornográfia, illetve a gyermekpornográfia. A szexuális tartalmakat tehát általánosságban megilleti az első alkotmánykiegészítés védelme és csak különösen indokolt esetben korlátozhatók. Harris felveti a kérdést, hogy lehet-e összefüggés az obszcenitás megállapíthatósága és a felvételek valóságtartalma között. Az Ashcroft kontra Free Speech Coalition ügyben ${ }^{14}$ a Legfelsőbb Bíróság egy olyan szövetségi törvény alkotmányosságát vizsgálta, amely tiltotta a kiskorúakat, illetve kiskorúnak látszó személyeket szexuális tartalmú cselekmény közben ábrázoló kép- és filmfelvételek - ideértve a digitálisan, számítógéppel elóállított felvételeket is - készítését. A bíróság ezt a jogszabályt alkotmánysértőnek ítélte amiatt, hogy túl tágan korlátozta a szólásszabadság jogát, és rámutatott arra, hogy nem minden szexuális tevekénység sérti a közízlést (prurient interest), amely tinédzsereket ábrázol. A bíróság a szólásszabadság korlátozását itt a közlés által ténylegesen okozott kár esetében engedné meg, a digitálisan előállított, nem a valóságot ábrázoló felvételeket pedig általánosságban erre alkalmatlannak ítélte. Harris álláspontja szerint ez az érvelés a deepfake pornográf felvételek esetében nem állja meg a helyét, hiszen az igenis kárt okoz a benne szereplö jó hírében, biztonságérzetében (Harris, 2019, 106.). Geoffrey Stone azonban rámutat, hogy a jelenlegi bírósági gyakorlat szerint ezek a felvételek nem minősülnek egyébnek, mint érzéki szórakoztatásnak (salacious entertainment), amelyet - hasonlóan a vulgáris szatírához és paródiákhoz - megillet az első alkotmánykiegészítés által biztosított védelem (Stone, 2017).

13 Miller v. California, 413 U.S. 15,23 (1973).

14 Ashcroft v. Free Speech Coalition 535 U. S. 234 (2002). 


\section{A platformszabályozás szerepe a bosszúpornó és a deepfake pornográfia eltávolításában}

A nagyobb platformok felhasználási feltételeit (bizonyos platformok esetében közösségi iránymutatásait) olvasva felfedezhetünk közös elveket és irányokat, a szabályrendszer azonban korántsem mondható egységesnek, az egyes platformokat vizsgálva igen színes kép rajzolódik ki. Természetesen ez jelentheti azt, hogy az online platformok a saját tevékenységükhöz legjobban illeszkedö, a hatékony védelmet leginkább megteremtő módon szabják fazonra a tartalommal és a felhasználói magatartásokkal kapcsolatos előírásaikat. A pesszimista álláspont szerint viszont a platformok effajta magánszabályozása egy olyan mértékben töredezett szabályozási környezetet eredményezhet, amelyben a jogkövetésre törekvő felhasználónak kihívást jelent eligazodni. A tanulmányban több kiemelt platform szabályrendszerét elemezve mutatjuk be a szexuális tartalmak szabályozásával kapcsolatos legfontosabb közös elemeket és különbségeket.

\section{A tiltott tartalmak köre}

A pornográf tartalmakra vonatkozó szabályok vizsgálatának alapkérdése, hogy az egyes szolgáltatók miként viszonyulnak az ilyen tartalmakhoz: tiltják vagy engedik azok feltöltését? Esetleg köztes megoldásként bizonyos korlátozásokkal engedik meg a szexuális tartalmak feltöltését? A legnagyobb platformok többsége elzárkózik a szexualitást és a meztelenséget ábrázoló tartalmaktól, a YouTube, a Facebook, a Tumblr, az Instagram és a Twitch mind tiltják az ilyen jellegü alkotásokat. A teljes tiltást, illetve a korlátozást alkalmazó online platformok esetében indokolt körbejárni azt is, hogy a tartalmaknak pontosan mely körét érinti a tilalom. A pornográfia egzakt definíciójához Potter Stewart bíró 1964-es szállóigévé vált mondata óta (,I know it when I see it." $\left.{ }^{15}\right)$ sem kerültünk sokkal közelebb, globális vagy uniós szinten elfogadott jogszabályi definíciója e tartalmak körének továbbra sincs. A platformszolgáltatók többsége ezért részletesen leírja, milyen típusú tartalmakat tilt vagy korlátoz, e korlátozás pedig a legtöbb vizsgált platform esetében igencsak széleskörü, ami komoly kérdéseket vet fel a szólásszabadság néhol indokolatlanul szigorúnak tünő korlátozásával összefüggésben. A tiltást alkalmazó platformok ugyanis nem kizárólag a pornográfiát, hanem a szexualitást és a meztelenséget általában tiltják. A Tumblr felnőtt tartalomként (adult content) definiál és töröl minden olyan fényképet, videót és GIF-et, amely valós emberi nemi szervet, női mellbimbókat ábrázol, vagy szexuális aktust mutat be (URL10).

15 Jacobellis v. Ohio, 378 U.S. 184, 197 (1964). 
Hasonló szigorral állapította meg a tiltott tartalmak körét a Facebook, ahol tilos a valóságban létező meztelen felnőttről készült, szexuális tevékenységet, illetve az ahhoz kapcsolódó magatartásokat és eszközöket (például szexuális játékszereket) explicit módon bemutató képek közzététele. A felhasználási feltételeiben a Facebook arról ír ${ }^{16}$, hogy alapvetően mindenfajta szexuális tartalmat eltávolít, hogy megakadályozza a hozzájárulás nélkül közzétett tartalmak megosztását, illetve a kiskorúakat ábrázoló tartalmak terjedését. A tartalmak visszaállítását az azt feltöltő felhasználó kérheti. 2019 júliusa és szeptembere között 30,3 millió tartalmat távolított el a platform a szexualitással kapcsolatos elöírások megsértése miatt, panasszal azonban mindössze a feltöltők 10\%-a élt. A panaszok alapján viszonylag kevés, 814.000 bejegyzést állítottak vissza. Valamivel engedékenyebb a YouTube, amely azokat a szexualitást és meztelenséget ábrázoló videókat moderálja, amelyek célja a szexuális örömszerzés. A célzat meghatározása ez esetben okozhat jogalkalmazási nehézségeket. A nyilvánvalóan pornográf tartalmak esetében vitathatatlan az elkészített felvétel célja, az erotikus müvészfilmekből kivágott jelenetek, vagy a hétköznapi élethelyzeteket fetisizáló (a platform példája szerint ilyen lehet az orvosi injekció vagy az evés) videók esetében azonban már nehezebb következtetéseket levonni mind a videót feltöltő felhasználó szándékát, mind a befogadó(k) percepcióját illetően. Azokat a videókat, amelyek esetében az örömszerzési célt nem tekinti megvalósultnak a szolgáltató, törlés helyett korhatárossá teszi. Korhatárossá tételt eredményezhet a szexuális tevékenységre ösztönző provokatív tánc, a szexuálisan explicit trágár nyelvezet, de a szereplők miliőhöz nem illő, indokolatlanul lenge ruházata is.

Az erőszakos, kegyetlen, megalázó fétisek az összes platform szerint moderálandók, akkor is, ha meztelenséget egyáltalán nem is tartalmaznak. Hasonló a helyzet a vérfertőzést, kannibalizmust, nekrofíliát, állatpornográfiát támogató, népszerüsítő tartalmakkal. A meztelenséget, szexualitást ábrázoló tartalmakat akkor is törlik a platformok, ha azokat digitálisan állították elő (például animációk) és valós szereplőket egyáltalán nem tartalmaznak. Nem ennyire elutasító a Snapchat és a Twitter, ahol korlátozásokkal ugyan, de megoszthatók szexualitást és meztelenséget bemutató tartalmak. A Snapchat például csak a kifejezetten pornográf tartalmak közzétételére és népszerüsítésére létrehozott felhasználói fiókokat tiltja, a szexualitás, a meztelenség előfordulását azonban nem zárja ki ${ }^{17}$ a felhasználói interakciók közül (URL11). A Twitter felhasználási feltételei kifejezetten szólnak arról, hogy a vállalat tisztában van azzal, hogy bizonyos tartalmak érzékeny témákat érintenek, így erőszakos vagy felnőtteknek szóló

16 Transparency Report.

17 Természetesen ez alól a gyermekekről készített felvételek kivételt képeznek. 
tartalmak lehetnek, de ezeket a véleménynyilvánítás szempontjából fontos tartalmaknak tekinti, így minimálisan korlátozza őket. Az ilyen tartalmakat nem szabad olyan helyen közzétenni, amely a platform szerkezetében kiemelt helyen jelenik meg (például élő közvetítésben), továbbá a felhasználó köteles megjelölni a fiókját, mint érzékeny tartalmat közlő fiókot. Ez esetben a platform minden felhasználó számára figyelmeztetést helyez el a megtekintés előtt (URL12). A tartalmak korhatárossá tétele is viszonylag széles körben elfogadott gyakorlat. A legtöbb szolgáltatásban van lehetöség arra, hogy a tartalom feltöltője megjelölje azokat a tartalmakat, amelyek nagykorúaknak szólnak. Ezek előtt a tartalmak elött figyelmeztetés jelenik meg és többnyire csak regisztrált felhasználók számára elérhetők. A platformok harmadik csoportját azok a szolgáltatások képezik, amelyek kimondottan szexuális tartalmak megosztására jöttek létre, esetükben nyilvánvalóan értelmetlen volna tiltásról beszélni. Azonban még az ilyen platformok rendeltetéséből sem következik az, hogy az összes tartalmi elöírás és szabály felett állnak, sőt egyes szabályok érvényesülésére fokozottabb figyelmet kell(ene) fordítaniuk. A felülvizsgált AVMS irányelv ${ }^{18}$ rendszerében éppen ezek azok a szolgáltatók, amelyeknek a tartalom ártalmasságával arányban a legszigorúbb intézkedéseket kell alkalmazniuk. Ezeknél a platformoknál is alapvető követelmény, hogy biztosítsák, kiskorúak ne férhessenek hozzá a szolgáltatáshoz. Európában igen nagy számban fordulnak elő ilyen weboldalak. Az Alexa ranking ${ }^{19}$ globális népszerüségi listáján megvizsgált első tíz pornográf jellegü weboldal (URL13) fele európai (fóként cseh és ciprusi) joghatóság alatt áll. Az AVMS irányelv átültetése még nem zárult le, ezért nyitott kérdés, hogy a tagállamok foglalkoznak-e majd érdemben a pornográf jellegü lekérhető szolgáltatások és videómegosztók szabályozásával, vagy intézményesített prüdériával ezekről a szolgáltatásokról tudomást sem véve próbálják megvalósítani az irányelv kiskorúak védelmére vonatkozó törekvéseit. Általános tartalmi szabályok természetesen ezekre a platformokra is irányadók, tehát a szolgáltatásukban nem szerepelhetnek olyan felvételek, amelyeknek a közzététele önmagában is büncselekményt valósít meg (például gyermekpornográfia).

\section{Beleegyezés nélkül közzétett szexuális felvételek és deepfake}

Az összes vizsgált platform zéró toleranciát hirdetett a hozzájárulás nélkül közzétett felvételekkel kapcsolatban, felismerve, hogy ez mások magánéletének

18 Az Európai Parlament és a Tanács 2010/13/EU irányelve a tagállamok audiovizuális médiaszolgáltatások nyújtására vonatkozó egyes törvényi, rendeleti vagy közigazgatási rendelkezéseinek összehangolásáról.

19 Az Alexa Internet, Inc. Az amazon.com cégcsoport egy kaliforniai székhelyü tagja, legfőképp az internetes oldalak forgalmának megbecsülését és rangsorolását tartalmazó weblapjáról ismert. 
súlyos megsértését jelenti. A bosszúpornót a platformok viszonylag egységesen definiálják: többnyire azokat a hozzájárulás nélkül közzétett képfelvételeket tekintik ide tartozónak, amelyek nem kereskedelmi céllal, privát helyzetben készültek, és amelyek szereplője (közel) meztelen, szexuális tevékenységet folytat vagy szexuális pózban látható (URL14). A hozzájárulás hiányának elsődleges indikátora a kontextus: a címek, képaláírások és hozzászólások tartalmából többnyire megítélhető, hogy bosszúpornóról van-e szó, de szintén valószínűsíti, hogy a felvételt hozzájárulás nélkül tették közzé, ha azt bejelentették a rendőrségen, panaszt tettek a platformnál, vagy a bulvármédiában megjelent a felvételek kiszivárgásának ténye. Ezek az indikátorok viszont már csak az utólagos moderálást segítik, ekkor azonban a károkozó magatartás már megvalósult, így a prevenciót nem szolgálják. A szolgáltatók a hozzájárulás nélkül közzétett tartalmak közé sorolják a titokban készített felvételeket is, továbbá a kukkolást, valamint az upskirtinget ${ }^{20}$, ahol a tartalom készítésének a módszere eleve kizárja a beleegyezést. A Facebook az áldozatsegítés érdekében egy új tartalomszürő technológiát is bevezetett, amelynek lényege, hogy az áldozatok vagy potenciális áldozatok feltölthetik azokat a képeiket egy szerverre, amelyeket nem kívánnak nyilvánosságra hozni. Ha a platformra valaki olyan képet próbál feltölteni, ami egyezik az adatbázisban szereplö felvétellel, azt a szolgáltató automatikusan blokkolja (URL15). Noha a megelőzés és az áldozatsegítés méltányolható és támogatható elképzelés, a gyakorlat adatvédelmi szempontból erősen kifogásolható, ezzel ugyanis a Facebook a világ legnagyobb érzékeny adatokból álló adatbázisának birtokosa lesz. A rendszer biztonsági hibái és az egyes felvételek kiszivárgása beláthatatlan károkat okozhat. A hozzájárulás nélkül közzétett felvételeket még a kimondottan pornográf felvételek megosztására létrehozott platformok is tiltják. A Twitter ugyan elfogadó a szexuális tartalmakkal kapcsolatban, a hozzájárulás nélkül közzétett tartalmakat azonban ez a platform is tiltja. A Twitter a bejelentés szempontjából két kategóriára bontja a tartalmakat: azokra, amelyeket bárki bejelenthet, és azokra, amelyeket csak az érintett bejelentésére távolítanak el. Mivel a platformszolgáltató alapvetően engedékeny, csak akkor távolítanak el tartalmat az olyan személyek kérésére, akik nem szereplöi a felvételeknek, ha az fenyegetést tartalmaz vagy nyilvánosságra hozza a szereplő kapcsolattartási adatait. A kimondottan pornográf tartalmakat kínáló platformoknál a felhasználási feltételek részeként szerepel az a kitétel, hogy a videó feltöltőjének, készítőjének írásos beleegyezést/hozzájárulást kell kérnie az összes sze-

20 Upskirting: jogosulatlan fénykép vagy videó készítése úgy, hogy a kamerát titokban egy női szoknya alá helyezik. 
replőtől a tartalom megosztása elött. Az amerikai jog a tartalom közzétevőinek kifejezett kötelezettségévé teszi, hogy olyan nyilvántartást vezessen, amelyen feltünteti a szereplők életkorát (U. S. Code $§ 2257$ ). E rendelkezés irányadó azokra a felvételekre, amelyek szexuálisan explicit tevékenységet ábrázolnak, akkor is, ha azokat digitálisan manipulálták. Arról azonban már nincs adat, hogy az ilyen platformok ellenőrzik-e ezeknek az írásos hozzájárulásoknak a meglétét, ahogyan arról sem, hogy hány esetben távolítanak el bejelentés alapján hozzájárulás nélkül közzétett tartalmakat. A jogszabályi rendelkezések érvényesüléséről ugyan nincs kézzel fogható adat, a sajtóban azonban markáns vélemények jelennek meg egyes pornográf tartalmakat kínáló platformokkal kapcsolatban. Így például a Guardian provokatív véleménycikke arról szól, hogy a Pornhub ahelyett, hogy azzal foglalkozna, hogy a koronavírus-járvány idején ingyenes prémiumtagságot biztosít Olaszországban, foglalkozhatna a saját pandémiájával, a bosszúpornóval (URL16). A hozzájárulás nélkül közzétett felvételeket azonosítás után ugyanis nehézkesen távolítja el a platform, és az algoritmusuk, amely azt hivatott biztosítani, hogy ezek a tartalmak ne jelenhessenek meg újra az oldalon, könnyen kijátszható. Egy másik cikk arra hívja fel a figyelmet, hogy a portál kegyetlenséget, bántalmazást és szexuális erőszakot tartalmazó felvételek közzétételét is megengedi, amelyek eltávolíttatása a rendelkezésre álló mechanizmusok ellenére is nehézkes (URL17). Jogszabályi rendelkezések hiányában a platformok a deepfake felvételeket is törekednek magánszabályozás révén kezelni. Több platformszolgáltató fellépett a hamisított felvételekkel szemben, így a deepfake pornográfiát betiltotta a Reddit, a Pornhub és a Twitter is.

\section{Szabályozási kezdeményezések az Egyesült Államokban}

Az Egyesült Államokban folyamatosan erősödnek azok a hangok, amelyek mind a bosszúpornó, mind a deepfake pornográfia szövetségi szintủ szabályozását, illetve büntetendővé nyilvánítását szorgalmazzák. A magánszféra büntetőjogi eszközökkel történő védelmének szükségessége már 1890-ben megfogalmazódott, amikor Samuel Warren és Louis Brandeis amellett foglaltak állást, hogy ez az egyén magánszférájának védelme érdekében kétséget kizáróan kívánatos (Warren-Brandeis, 1890). Szövetségi szinten nem született még jogszabály a bosszúpornó büntethetővé nyilvánításáról. Pontosabban 2004-ben már született egy szövetségi törvény, amely a digitális kukkolást hivatott megelőzni (Video Voyeurism Prevention Act) azáltal, hogy tiltja olyan felvételek készítését és közzétételét, amelyek más embert ruhátlanul 
ábrázolnak, ha az érintett nem adta hozzájárulását a felvétel elkészítéséhez és észszerúen elvárhatta a magánszférája védelmét. A fenti jogszabály azonban a klasszikus bosszúpornót nem rendeli büntetni, mivel a felvételek elkészítésére a sértett hozzájárulásával került sor. Állami szinten már vannak törekvések a bosszúpornó-jelenség kriminalizálására, így az Egyesült Államok több tagállama büntetni rendeli azt is, ha valaki hozzájárulás nélkül tesz hozzáférhetővé más személyről készült pornográf felvételeket. Az állami szinten bevezetett jogszabályokat több kritika is érte, köztük a New York állam által bevezetett törvényt (URL18), amellyel kapcsolatban a legfőbb ellenérv az volt, hogy továbbra is a zaklatással kezeli analóg módon a hozzájárulás nélkül közzétett pornográf felvételeket, amelyek estében így a tényállásszerü elkövetéshez szükséges a károkozási szándék. Nem csak New York államban létezik a párhuzam, összesen 24 állam fogalmaz meg vétkességi követelményt, ami azt jelenti, hogy az elkövető szándékának arra kell irányulnia, hogy kárt okozzon másnak. Citron és Franks arra is felhívják a figyelmet, hogy a zaklatás tényállásának eleme a rendszeresség, így aki csak egy videót tesz közzé, nem valósítja meg (Citron-Franks, 2014, 345.). A szerzőpáros arra is rámutat, hogy a hozzájárulás nélkül közzétett felvételeket gyakran azonosítjuk azzal az esettel, amikor a sértett a felvétel készítésébe beleegyezik, vagy maga küld szexuális tartalmú felvételt partnerének, később pedig ezeket a felvételek kerülnek nyilvánosságra, amelyhez a sértett nem adta hozzájárulását. A bosszúvágyból nyilvánosságra hozott szexuális tartalmú felvételek azonban jóval több és mélyebben gyökerező problémát érintenek néhány felelőtlenül elkészített felvételnél, a szerzők szerint bosszúpornóként kell kezelni a titokban, vagy a nyíltan, de a sértett beleegyezése nélkül elkészített felvételeket is, hiszen az ezek nyilvánosságra hozatalával történő zsarolás a párkapcsolati erőszak egyik formája lehet (Citron-Franks, 2014, 346.). Több jogszabály hivatkozik arra, hogy a sértettnek akkor van joga fellépni a bosszúvágyból közzétett szexuális felvételekkel szemben, ha észszerü elvárása lehetett volna a magánszféra védelme. Douglas Harris kiemeli, hogy a deepfake pornográfia esetében ez nem feltétlenül jelent kapaszkodót, hiszen a bemutatott aktus meg sem történt, a felvételeken pedig egy másik ember intim testrészei látszanak (Harris, 2019). A hozzájárulás nélkül közzétett pornográf felvételek esetében tehát valamilyen magántermészetü, valós információ közzététele sérti az egyén magánszféráját, a valótlan felvételek azonban nem tartoznak a sértett magánszférájának körébe (URL19). Mivel a legtöbb olyan webes applikáció, amelyik képes ilyen montázst készíteni, föként a közösségi oldalakon nyilvánosan elérhető képanyagból dolgozik, ezért szintén nehézkesen lehetne felhozni a képmás védelméhez való jogot. Elképzelhető, hogy az lép fel sértettként, 
akinek az intim testrészei megjelennek a videóban (URL20), azonban ezeket a képsorokat többnyire nyilvánosan elérhető pornográf felvételekből vágják ki, amelyek szereplői - vélhetően - beleegyeztek a kamerák előtt folytatott közösülésbe és ennek nyilvánosságra hozatalába. Szövetségi szinten még nem született ezeket a jelenségeket kezelő norma, noha már voltak erre irányuló kezdeményezések. 2016-ban az intim magánszféra védelméről szóló törvényjavaslatot terjesztették a kongresszus elé (Ending Nonconsensual Online User Graphic Harassment Act - ENOUGH), 2018-ban pedig kifejezetten a deepfake pornográfia tilalmáról szóló törvényjavaslatot (The Malicious Deep Fake Prohibition Act - MDFPA), de végül egyikből sem lett elfogadott jogszabály. A tényleges elkövetők beazonosítása ebben az esetben nagyon nehéz amiatt, mert anonim módon töltik fel a tartalmakat, proxy szervert vagy anonimizáló webböngészőt (például TOR) használnak. Ebből kifolyólag - ahogyan Rebecca Delfino is felhívja erre a figyelmet, nagyon sok sértett a platformszolgáltató felelősségre vonását kezdeményezi, ennek sikere azonban csekély esélylyel kecsegtet (Delfino, 2019). Az amerikai CDA (Communications Decency Act) 230. szakasza immunitást biztosít a közvetítő szolgáltatóknak a harmadik személyek által feltöltött jogellenes tartalmakért viselt felelősség alól. Az immunitás azonban nem korlátlan, a szolgáltatóknak értesítés alapján a büntetőjogi normát sértő tartalmakat el kell távolítaniuk. Azonban még ha sor is kerül a felvétel ideiglenes vagy végleges eltávolítására a kár már megtörtént, a felvétel nyilvánosságra került, és ahogy a modern mondás szól, ami egyszer az internetre felkerült, azt már nem lehet onnan eltávolítani. Delfino a Barnes kontra Yahoo! Inc. ítéletet ${ }^{21}$ hozza példaként, amelyben a bíróság úgy határozott, hogy a szolgáltató nem tehető felelőssé azért, mert nem vagy nem megfelelő sebességgel távolította el a felperes exbarátja által feltöltött képeket. A tartalmak utólagos eltávolítása ugyanakkor nem feltétlenül segít az áldozattá vált személyen. Az amerikai Legfelsőbb Bíróság a New York kontra Ferber ügyben ${ }^{22}$ megállapította, hogy a gyermekpornográfia esetében a kiskorúakat ábrázoló fénykép- és filmfelvételek közzététele végleges lenyomata a kiskorú bántalmazásának, a szexuális bántalmazással okozott kárt pedig megtöbbszörözi a felvétel közzététele és minden egyes megtekintése. Nincs ez másként a hozzájárulás nélkül közzétett pornográf felvételek felnőtt áldozatainál sem. A büntetőjogi fenyegetettség ebben az esetben tehát a potenciális elkövetők elrettentését és a prevenciót szolgálná.

21570 F.3f 1096, 1105 (9th Cir. 2009).

22 New York v. Ferber 458 U.S. 747 (1982). 


\section{Szabályozási kezdeményezések Magyarországon és Európában}

Németország a közösségi médiára - pontosabban minden felhasználói tartalmak tárolását lehetővé tévő platformra - irányadó szabályok hatékony kikényszerítésének érdekében fogadott el törvényt 2017-ben (Gesetz zur Verbesserung der Rechtsdurchsetzung in sozialen Netzwerken, a továbbiakban: NetzDG; URL21). Ez arra kötelezi a szolgáltatókat, hogy távolítsák el azokat a tartalmakat, amelyek a német jog szerint jogszerütlennek minősülnek, a panaszkezelés és a moderáció átláthatóvá tétele érdekében pedig vezessenek nyilvántartást az eltávolított tartalmakról. A német büntetö törvénykönyv szerint jogszerütlennek minősített tartalmak körébe tartozik a becsületsértés (186.§), a szándékos becsületsértés (187.§) és az intim magánszféra megsértése fényképfelvételek készítése által (201a.§). Franciaországban a Digitális köztársaságról szóló törvény (Loi pour une République numérique) 2016 óta büntetni rendeli a bosszúpornó közzétevöit (URL22), ilyen felvételek közzétételéért két év szabadságvesztés és 60.000 eurós bírság szabható ki. Olaszországban 2019 tavasza óta büncselekménynek számít bosszúból, hozzájárulás nélkül közzétenni szexuális jellegü felvételeket (URL23). Az Egyesült Királyság büntető kódexe (Criminal Justice and Courts Act) 2015 óta rendelkezik arról, hogy a magántermészetű fénykép- és videófelvételek fájdalom, szenvedés okozásának szándékával (intent to cause distress) történő közzététele szabadságvesztéssel büntethető. Rosalind Setterfield rámutat, hogy ezek a szabályok azonban csak Angliára és Walesre irányadók (Setterfield, 2019), lehetőség van azonban a bosszúpornó közzétevőivel szemben más jogszabályok alapján fellépni. Nevezetesen:

- a rosszindulatú kommunikációról szóló törvény (Malicious Communications Act) és a kommunikációról szóló törvény (Communications Act) alapján, amelyek egyaránt tartalmaznak a súlyosan sértő (grossly offensive) közlések visszaszorítását célzó rendelkezéseket;

- a zaklatástól való védelemről szóló törvény (The Protection from Harassment Act) alkalmazható, ha az elkövetö tevékenysége rendszeres;

- a gyermekvédelmi törvény (Protection of Children Act) alkalmazható, ha a sértett még nem volt nagykorú.

Magyarországon sem a bosszúpornó, sem a deepfake pornográfia nem jelenik meg önálló tényállásként a büntető törvénykönyvben. A magyar Btk.-nak viszont több olyan szakasza is van, amely alkalmazható ezekre az esetekre. A sértettnek zaklatás, rágalmazás, szexuális kényszerítés, zsarolás, valamint be- 
csület sértésére alkalmas hamis hang- vagy képfelvétel készítése miatt is lehetősége van a rendőrséghez fordulni. Egyik tényállás sem kifejezetten a tárgyalt cselekmények kriminalizálását szolgálja, ezért a tényállási elemeknek való megfelelés vizsgálatakor számos problémába ütközhet a jogalkalmazó. A szexuális kényszerítés (Btk. 196. §) esetében például tényállási elem, hogy maga az aktus is a sértett akarata ellenére történjen. A hozzájárulás nélkül közzétett felvételek esetében azonban a sértett az aktusba többnyire beleegyezik, gyakran abba is, hogy arról felvétel készüljön, a hozzájárulás kizárólag a közzétételre nem terjed ki. A zaklatás tényállása (Btk. 222. §) szintén nem minden esetben alkalmazható, hasonlóan az amerikai szabályokhoz, ugyanis hazánkban is feltétele a cselekmény elkövetésének a rendszeres és tartós háborgatás, amely egyetlen felvétel közzététele esetén nem valósul meg. A rágalmazás tényállása (Btk. 226. §) elméletben alkalmazható a bosszúból közzétett szexuális felvételek esetén, már amennyiben egy videófelvételt tényállításnak tekintünk. A Btk. indokolása szerint ,tényállitás az olyan nyilatkozat, amely a múltban megtörtént vagy a jelenben megtörténö eseményre, jelenségre vagy állapotra vonatkozik." A filmfelvétel, amely egy szexuális aktus megtörténtét mutatja be, önmagában még nem nyilatkozat, ennek közzététele, a feltöltő által hozzáfüzött magyarázat, leírás azonban már felfogható ekként. A zsarolás tényállásának az elkövető haszonszerzési célzata szükségszerủ eleme (Btk. 367. §), tehát a bosszúból közzétett szexuális felvételek esetén csak akkor alkalmazható, ha az elkövető anyagi motiváció miatt oszt meg intim felvételeket, vagy helyezi ezek feltöltését kilátásba. A deepfake felvételek esetében megoldást jelent a Btk. 226/B. szakasza, amely a becsület csorbítására alkalmas hamis kép- vagy hangfelvételek készítését és nyilvánosságra hozatalát is büntetni rendeli. A bosszúpornó és a visszaélés-szerúen közzétett deepfake pornográfia esetében az önálló kriminalizálás azért is megfontolandó, mert az előbbiekben bemutatott tényállásokat csak akkor lehet rájuk alkalmazni, ha a közzététel teljes mértékben kimeríti valamelyik tényállást. A tényállásszerüség elvéből következik, hogy a Btk.-t nem lehet kiterjesztően értelmezni és az analógia alkalmazására is csak nagyon szük körben van lehetőség; az elkövető terhére például analógiát alkalmazni nem lehet.

\section{Konklúzió}

A hozzájárulás nélkül közzétett pornográf felvételek és a hamisított felvételek által okozott probléma kétséget kizáróan valós. Az előfordulás számossága és az áldozatoknak okozott kárra tekintettel e cselekmények büntetőjogi fenye- 
getettsége egyáltalán nem tűnik túlzó lépésnek. Az, hogy az USA, Németország, Franciaország, Olaszország és az Egyesült Királyság is megtette a kezdő lépéseket ebbe az irányba azt mutatja, hogy olyan problémáról van szó, amely országtól és régiótól független, és amelyre figyelni kell. Napjainkban „nem létezik éles határ a pornográfia és az internetes kultúra egyéb szegmensei között, a mindennapok részévé váltak ezek a tartalmak, nem keltenek többé megütközést" (URL24), ezért a szabályozásnak sem szabad szemérmesnek maradnia, ha a pornográf tartalmak által okozott sérelmekröl van szó. A szabályozási megoldások egyelöre még vetnek fel kérdéseket. Alapjogi szempontból talán az egyik legjelentősebb az, hogy az egyének számára okozott sérelem indokolja-e a közléstípus előzetes, teljes tilalmát és a szólásszabadság büntetőjogi eszközökkel történő korlátozását. Egyes amerikai szakirodalmi források szerint erre a kérdésre a válasz igen, hiszen a sérelmek utólagos orvoslása, a reparáció nehezen lehetséges, így inkább a prevencióra szükséges összpontosítani. Ezek a sérelmek mélyebb sebet ejtenek a társadalmon, nem csupán egymástól független egyéni jogsérelmek, hanem alkalmasak ugyanis a nemek közötti egyenlőtlenségek konzerválására, sőt, erősítésére. Az egyelőre kezdetleges állami szabályozás hézagjait jelenleg a platformok magánszabályozás révén töltik ki. Ez egyrészről üdvözlendő, hiszen a felhasználók számára a védelem minimális szintje biztosított. Nem szerencsés viszont abból a szempontból, hogy az egyes platformok eltérő szigorral, szemléletmóddal szabályozzák ugyanazokat a jelenségeket. A felhasználók számára ez sokszor bizonytalan helyzetet teremt, ami a hatékony jogérvényesítés korlátja lehet. Nagyobb probléma viszont, hogy sokszor a legártalmasabb tartalmakat hordozó platformok azok, amelyek a legalacsonyabb szintü védelmet nyújtják. Az ilyen szolgáltatókat indokolt lenne szigorúbb állami ellenőrzés alá vonni, amely jelenthet egyrészt médiajogi jellegü tartalomkorlátozást célzó intézkedéseket a sérülékenyebb felhasználói csoportok, például a kiskorúak védelme érdekében, másrészt jelentheti a meglévő kötelezettségek teljesítésének szorosabb figyelemmel kísérését. Az állami és uniós szintü platformszabályozási elképzeléseknek a hatékony védelem biztosítása érdekében bizonyos mértékben el kell szakadnia a techóriások pellengérre állításától. Noha ezek a nagy platformok az elért felhasználók nagy száma miatt sok problémát tudnak okozni, a sok kisebb platform, amelyeknek jelenleg nem jut elég szabályozói figyelem, szintén képesek veszélyeztetni több demokratikus értéket, illetve egyes egyéni jogokat. 


\section{Felhasznált irodalom}

Citron, D. K. - Franks, M. A. (2014): Criminalizing Revenge Porn. Wake Forest Law Review, 49, 345-391.

Delfino, R. (2019): Pornographic Deepfakes - Revenge Porn's Next Tragic Act - The Case for Federal Criminalization. Fordham Law Review, 3, 887-938. DOI: 10.2139/ssrn.3341593

Dworkin, R. (1981): Is There a Right to Pornography? Oxford Journal of Legal Studies, 177. DOI: $10.1093 /$ ojls/1.2.177

Harris, D. (2019): Deepfakes: False Pornography Is Here and the Law Cannot Protect You. Duke Law \& Technology Review, 1, 99-127.

Kiss T. - Parti K. - Prazsák G. (2019): Cyberdeviancia. Budapest: Dialóg Campus Kiadó

Koltay A. (2009): A szólásszabadság alapvonalai: magyar, angol, amerikai és európai összehasonlitásban. Budapest: Századvég Kiadó

Koppelman, A. (2016): Revenge Pornography And First Amendment Exceptions. Emory Law Journal, 3, 661-693.

Mill, J. S. (1994): A szabadságról. Budapest: Századvég - Readers International

Post, R. C. (1988): Cultural Heterogeneity and Law: Pornography, Blasphemy, and the First Amendment. California Law Review, 76, 297-309. DOI: 10.2307/3480615

Schauer, F. (1979): Speech and "speech" - obscenity and "obscenity". An exercise in the interpretation of constitutional language. Georgetown Law Journal, 67, 899-933.

Setterfield, R. C. (2019): The regulation of ,revenge porn' in England and Wales: are existing legal solutions effective? Doctoral thesis, University of Surrey

Stone, G. R. (2017): Sex and the Constitution: Sex, Religion, and Law from America's Origins to the Twenty-First Century. New York: Liveright.

Sunstein, C. R. (1986): Pornography and the First Amendment. Duke Law Journal, 4, 589-627. DOI: $10.2307 / 1372485$

Török B. (2018): Szabadon szólni, demokráciában: a szólásszabadság magyar doktrínája az amerikai jogirodalom tükrében. Budapest: HVG-ORAC

Warren, S. D. - Brandeis, L. D. (1890): The Right to Privacy. Harward Law Review, 5, 193-220. DOI: $10.2307 / 1321160$

\section{A cikkben található online hivatkozások}

URL1: Ruvolo, J. (2011): How Much of the Internet is Actually for Porn. https://www.forbes. com/sites/julieruvolo/2011/09/07/how-much-of-the-internet-is-actually-for-porn/

URL2: Zsilák Sz. (2019): A bosszúpornó, az egy nagyon jó bosszú. https://abcug.hu/a-bosszuporno-az-egy-nagyon-jo-bosszu/ 
URL3: Willsher, K. (2020): Paris mayoral candidate drops out over sex video scandal. https:// www.theguardian.com/world/2020/feb/14/paris-mayoral-candidate-benjamin-griveaux-sex-video-scandal

URL4: Braun, E. (2020): Griveaux scandal revives France's will to regulate social media. https:/www.politico.eu/article/benjamin-griveaux-sex-tape-scandal-paris-mp-revives-franceswill-to-regulate-social-media/

URL5: Joób S. (2019): Másik pornószájton jelentek meg a Borkai-videók. https://index.hu/belfold/2019/10/10/borkai_zsolt_botrany_rakosfalvy_zoltan_pornhub_video_torles/

URL6: Tinibosszúpornó borzolja a kedélyeket Salgótarjánban. https://hvg.hu/itthon/20160122_ Tini_bosszuporno_borzolja_a_kedelyeket_Sa

URL7: Kelly, C. (2019): Facebook's Anti-Revenge Porn Tools Failed to Protect Katie Hill. https://www.wired.com/story/katie-hill-revenge-porn-facebook/

URL8: Turton, W. - Justus, M. (2018): “Deepfake” videos like that Gal Gadot porn are only getting more convincing — and more dangerous. https:/www.vice.com/en_us/article/qvm97q/deepfake-videos-like-that-gal-gadot-porn-are-only-getting-more-convincing-and-more-dangerous

URL9: Hollister, S. (2018): Scarlett Johansson slams deepfakes, says she can 't stop the internet from pasting her face on porn. https://www.theverge.com/2018/12/31/18163351/scarlett-johansson-slams-deepfakes-internet-lost-cause

URL10: Adult content. https://tumblr.zendesk.com/hc/en-us/articles/231885248

URL11: Community Guidelines. https://www.snap.com/en-US/community-guidelines

URL12: Sensitive media policy. https://help.twitter.com/en/rules-and-policies/media-policy

URL13: The top 500 sites on the web. https://www.alexa.com/topsites/category/Top/Adult

URL14: Felnőttek szexuális kizsákmányolása. https://www.facebook.com/communitystandards/sexual_exploitation_adults

URL15: Detecting Non-Consensual Intimate Images and Supporting Victims. https://about.fb. com/news/2019/03/detecting-non-consensual-intimate-images/

URL16: Mahdawi, A. (2020): Pornhub should forget the coronavirus and focus on its own pandemic: revenge porn. https://www.theguardian.com/commentisfree/2020/mar/14/pornhub-forget-coronavirus-focus-on-pandemic-revenge-porn

URL17: Grant, H. (2020): World's biggest porn site under fire over rape and abuse videos. https://www.theguardian.com/global-development/2020/mar/09/worlds-biggest-porn-site-under-fire-over-videos-pornhub

URL18: Ellis, E. G. (2019): New York's Revenge Porn Law Is a Flawed Step Forward. https:// www.wired.com/story/new-york-revenge-porn-law/

URL19: Dold, K. (2018): Face-Swapping Porn: How a Creepy Internet Trend Could Threaten Democracy. https://www.rollingstone.com/culture/culture-features/face-swapping-porn-howa-creepy-internet-trend-could-threaten-democracy-629275/

URL20: Alptraum, L. (2020): Deepfake Porn Harms Adult Performers, Too. https://www.wired. $\mathrm{com} /$ story/deepfake-porn-harms-adult-performers-too/ 
URL21: Gesetz zur Verbesserung der Rechtsdurchsetzung in sozialen Netzwerken. https://www. gesetze-im-internet.de/netzdg/BJNR335210017.html

URL22: France: Digital Republic Law sanctions against revenge porn. https://www.coe.int/en/ web/cybercrime/-/france-digital-republic-law-sanctions-against-revenge-porn

URL23: Tidman, Z. (2019): Italy criminalises revenge porn with prison sentences of up to six years. https://www.independent.co.uk/news/world/europe/revenge-porn-italy-five-star-league-red-code-bill-a8853591.html

URL24: Pap L. (2020): Pornó: zugbizniszböl a fösodorba és a mindennapokba. https://mandiner.hu/cikk/20200213_porno 